\title{
Modeling and mapping the habitat suitability and the potential distribution of Arboviruses vectors in Morocco
}

\author{
Outammassine Abdelkrim ${ }^{1}$, Boussaa Samia ${ }^{2,3}$, Zouhair Said ${ }^{1,4}$, and Loqman Souad ${ }^{1, *}$ \\ ${ }^{1}$ Laboratory of Microbiology and Virology, Department of Medical Biology, Faculty of Medicine and Pharmacy, Cadi Ayyad University, \\ PO Box 7010, 40000 Marrakech, Morocco \\ ${ }^{2}$ ISPITS-Higher Institute of Nursing and Health Technology, 40000 Marrakech, Morocco \\ ${ }^{3}$ Ecology and the Environment Laboratory L2E (URAC 32, CNRST ERACNERS 06), Faculty of Sciences Semlalia, Cadi Ayyad \\ University, 2390-40080 Marrakech, Morocco \\ ${ }^{4}$ Laboratory of Bacteriology-Virology, Avicienne Hospital Military, 40000 Marrakech, Morocco
}

Received 15 October 2020, Accepted 13 March 2021, Published online 14 April 2021

\begin{abstract}
Mosquitoes transmit several agents of diseases and the presence of different species represents a threat to animal and public health. Aedes and Culex mosquitoes are of particular concern giving their potential vector competence for Arbovirus transmission. In Morocco, the lack of detailed information related to their spatial distribution raises major concerns and hampers effective vector surveillance and control. Using maximum entropy (Maxent) modeling, we generated prediction models for the potential distribution of Arboviruses vectors (Aedes aegypti, Ae. vexans, Ae. caspius, Ae detritus, and Culex pipiens) in Morocco, under current climatic conditions. Also, we investigated the habitat suitability for the potential occurrence and establishment of Ae. albopictus and Ae. vittatus recorded only once in the country. Prediction models for these last two species were generated considering occurrence datasets from close countries of the Mediterranean Basin, where Ae. albopictus is well established, and from a worldwide database for the case of Ae. vittatus (model transferability). With the exception of Ae. vittatus, the results identify potential habitat suitability in Morocco for all mosquitos considered. Existing areas with maximum risk of establishment and high potential distribution were mainly located in the northwestern and central parts of Morocco. Our results essentially underline the assumption that Ae. albopictus, if not quickly controlled, might find suitable habitats and has the potential to become established, especially in the northwest of the country. These findings may help to better understand the potential distribution of each species and enhance surveillance efforts in areas identified as high risk.
\end{abstract}

Key words: Aedes and Culex, Arboviruses, Maxent, Morocco, Potential distribution, Habitat suitability.

Résumé - Modélisation et cartographie de l'aptitude de l'habitat et de la distribution potentielle des vecteurs d'Arbovirus au Maroc. Les moustiques transmettent plusieurs agents de maladies et la présence de différentes espèces représente une menace pour la santé animale et publique. Les moustiques Aedes et Culex sont particulièrement préoccupants compte tenu de leur compétence de vecteur potentiel pour la transmission des Arbovirus. Au Maroc, le manque d'informations détaillées relatives à leur répartition spatiale soulève des préoccupations majeures et entrave une surveillance et un contrôle efficaces des vecteurs. En utilisant la modélisation de l'entropie maximale (Maxent), nous avons généré des modèles de prédiction pour la distribution potentielle des vecteurs d'Arbovirus (Aedes aegypti, Ae. vexans, Ae. caspius, Ae. detritus et Culex pipiens) au Maroc, dans les conditions climatiques actuelles. De plus, nous avons étudié l'adéquation de l'habitat pour l'occurrence et l'établissement potentiels d'Ae. albopictus et Ae. vittatus signalés une seule fois dans le pays. Des modèles de prévision pour ces deux dernières espèces ont été générés en tenant compte des ensembles de données d'occurrence des pays voisins du bassin méditerranéen, où Ae. albopictus est bien établi et provient d'une base de données mondiale pour le cas d'Ae. vittatus (transférabilité du modèle). À l'exception d'Ae. vittatus, les résultats identifient la pertinence potentielle de l'habitat au Maroc pour tous les moustiques considérés. Les zones existantes présentant un risque maximal d'établissement et une distribution à fort potentiel étaient principalement situées dans le nord-ouest et le centre du Maroc. Nos résultats soulignent essentiellement l'hypothèse qu'Ae. albopictus, s'il n'est pas rapidement contrôlé, pourrait trouver des habitats convenables et a le potentiel de s'établir, en particulier dans le nord-ouest du pays. Ces résultats peuvent aider à mieux comprendre la répartition potentielle de chaque espèce et à renforcer les efforts de surveillance dans les zones identifiées comme à haut risque.

\footnotetext{
*Corresponding author: s. logman@uca.ma
}

This is an Open Access article distributed under the terms of the Creative Commons Attribution License (https://creativecommons.org/licenses/by/4.0), which permits unrestricted use, distribution, and reproduction in any medium, provided the original work is properly cited. 


\section{Introduction}

Over the past few years, arboviruses (arthropod-borne viruses) have (re)emerged at an alarming rate, posing a significant health threat to millions of people worldwide [128]. Dengue virus epidemics (DENV) are responsible for about 50-100 million infections each year [72], Chikungunya virus (CHIKV) is still ongoing periodically since the mid-2000s [123], West Nile virus (WNV) was first introduced to the United States in 1999 and rapidly spread and became endemic throughout North America [131], and most recently Zika virus (ZIKV) quickly spread all over the Western Hemisphere [91] and was declared a Public Health Emergency of International Concern in 2016 [153]. All serve as examples of how explosive and unpredictable arboviral infections outbreaks could be.

Many arboviruses vectored by mosquitoes (Diptera: Culicidae) have expanded their geographic range and managed to achieve greater expansion in areas where they did not exist before. Human movement, global trade, climate change, and availability of susceptible mosquito vectors has increased the introduction of diseases to populations that otherwise would have been safely out of reach [35, 88]. In Morocco, as for the majority of North Africa and Middle East countries, the epidemiological situation of arboviruses remains poorly or even uncharacterized [61]. Anopheles species, vectors of malaria, have always been the most studied in Morocco [10, 25, 63, 74-76, 110], while other genera such as Aedes and Culex remained poorly studied and characterized. Detailed information related to their spatial distribution is scarce, scattered, and rather inaccurate, which hampers effective surveillance and control, especially for the ones representing significant public health threats and listed among Culicidae of Morocco or Africa-Mediterranean [141, 142]. This is completely true for the case of Aedes aegypti (Linnaeus, 1762), Aedes albopictus (Skuse, 1895), Aedes vittatus (Bigot, 1861), Aedes vexans (Meigen, 1830), Aedes caspius (Pallas, 1771), Aedes detritus (Haliday, 1833) and Culex pipiens (Linnaeus, 1758), known to be potentially vector competent for Arbovirus transmission (Table 1).

Recently, ecological niche modeling has been used intensively as the best tool with which to assess, quantify and characterize the risk of mosquitoes' potential distribution in a defined locality, by relating observed occurrence to environmental data $[43,88]$. The approach can provide reliable results even for species with scarce occurrence records [119].

In the context of preventing arbovirus outbreak expansion, knowledge of Ae. aegypti and Ae. albopictus potential distribution, using ecological niche modeling, has already been shown to help predict the spread of viruses transmitted, such as chikungunya, dengue, and Zika viruses, at both regional and international scales [18, 24, 89]. The work of Kraemer et al. [88] is the best example of the importance of emphasizing the potential threat of vector spread and availability on anticipating arboviruses transmission, especially after the Zika virus emerged in Brazil within a few months of this study's publication [153].

In the present study, we generated prediction models for the potential distribution of Ae. aegypti, Ae. vexans, Ae. caspius, $A e$. detritus and Cx. pipiens in Morocco. Also, we estimated and evaluated the habitat suitability for the potential occurrence and establishment of Ae. albopictus and Ae. vittatus, recorded only once in the country. The results produced herein should be considered as a starting point to target and enhance surveillance efforts in areas identified as high risk.

\section{Materials and methods}

\section{Mosquito records}

From the Culicidae of Morocco database, tracing back the history of mosquitos in the country from 1916 to 2017, we extracted 9 geo-positioned points for Ae. aegypti and Ae. vexans, 59 for Ae. caspius, 53 for Ae. detritus, and 257 for $C x$. pipiens [140]. Dataset records for Ae. albopictus and Ae. vittatus were obtained from the Global Biodiversity Information Facility (https://www.gbif.org) and the worldwide database compiled by Kraemer et al. [68, 88, 90]. The downloaded dataset for each species was separately filtered by excluding records with missing latitude or longitude and duplicate records sharing the same coordinates [117]. Over 1550 observed points of Ae. albopictus were retained for predictions from close countries of the Mediterranean Basin, where Ae. albopictus is well established and was suspected to be the source of the identified population collected in Morocco in 2016 [17]. For Ae. vittatus, 429 assembled points were retained and used for predictions at a global scale, given that the species was recorded only once in Morocco without any detailed information regarding its geolocation $[141,142]$ and also given the scarce occurrence records on the species presence at the regional scale. During model training, the final records were randomly split 20 times into training and testing data in a proportion of 70:30.

\section{Environmental predictor variables}

Any living species can only achieve and maintain its life cycle within a limited range of environmental characteristics. For mosquitos, temperature and precipitation are the most important factors that condition their survival and geographical distribution. Thus, to characterize the current climate conditions, we used data from WorldClim (version 1.4, https://www. worldclim.org). This includes altitude and 19 bioclimatic variables, representing 50 years (1950-2000) of monthly derived temperature and precipitation data, collected from weather stations all over the world at $1 \times 1 \mathrm{~km}(30 \mathrm{arc} \mathrm{sec})$ spatial resolution (Table 2).

To select an optimal variable set, a prior modeling test was performed with all of the 20 environmental variables, so as to get a general overview of the variables contributing most to each modeled species. Briefly, the approach consists of running multiple models and each time excluding variables that contribute less or are less informative by comparing model performance with and without the considered variable, which markedly decreases when excluding variables with important contributions and vice versa [84]. To determine the contribution of environmental variables, the Jackknife test option in Maxent was applied [121]. Variables were then submitted to statistical analysis for covariation and collinearity investigation (S1 file 
Table 1. Overview of the medical importance of certain mosquitos tracked in Morocco.

\begin{tabular}{|c|c|c|c|c|c|}
\hline Species & $\begin{array}{c}\text { Period of record in } \\
\text { Morocco }\end{array}$ & $\begin{array}{l}\text { Number of } \\
\text { times }\end{array}$ & Reference & Arboviruses transmitted & Reference \\
\hline \multirow[t]{6}{*}{ Ae. aegypti } & $1916-1997$ & 9 & {$[8,39,67,78,149]$} & Zika virus (ZIKV) & {$[47,65,71,92,103,129]$} \\
\hline & & & & Chikungunya virus (CHIKV) & {$[38,45,102]$} \\
\hline & & & & Dengue virus (DENV) & [9] \\
\hline & & & & Mayaro virus (MAYV) & {$[86]$} \\
\hline & & & & Uganda $S$ virus (UGSV) & {$[83]$} \\
\hline & & & & Yellow fever virus (YFV) & [95] \\
\hline \multirow[t]{8}{*}{ Ae. albopictus } & 2016 & 1 & {$[17]$} & Zika virus (ZIKV) & {$[41,96,137]$} \\
\hline & & & & Chikungunya virus (CHIKV) & [134] \\
\hline & & & & Dengue virus (DENV) & [32] \\
\hline & & & & Japanese Encephalitis virus (JEV) & {$[48]$} \\
\hline & & & & Rift Valley fever virus (RVFV) & [33] \\
\hline & & & & Usutu virus (USUV) & {$[124]$} \\
\hline & & & & West Nile virus (WNV) & [34] \\
\hline & & & & Yellow fever virus (YFV) & {$[6,7]$} \\
\hline \multirow[t]{4}{*}{ Ae. vittatus } & 1916 & 1 & {$[67]$} & Zika virus (ZIKV) & {$[50,51]$} \\
\hline & & & & Chikungunya virus (CHIKV) & [49] \\
\hline & & & & Dengue virus (DENV) & {$[105]$} \\
\hline & & & & Yellow fever virus (YFV) & {$[70]$} \\
\hline \multirow[t]{5}{*}{ Ae. vexans } & $1947-2016$ & 9 & {$[57,66,78,79,109]$} & Zika virus (ZIKV) & {$[58,69]$} \\
\hline & & & & Rift Valley fever virus (RVFV) & [112] \\
\hline & & & & St. Louis Encephalitis virus (SLEV) & [77] \\
\hline & & & & Tahyna virus (TAHV) & [107] \\
\hline & & & & West Nile virus (WNV) & {$[62]$} \\
\hline \multirow[t]{5}{*}{ Ae. caspius } & $1946-2010$ & 59 & {$[57,150]$} & Sindbis virus (SINV) & {$[98]$} \\
\hline & & & & Tahyna virus (TAHV) & [122] \\
\hline & & & & Usutu virus (USUV) & [44] \\
\hline & & & & Rift Valley fever virus (RVFV) & {$[139,145]$} \\
\hline & & & & West Nile virus (WNV) & {$[59,116]$} \\
\hline \multirow[t]{5}{*}{ Ae. detritus } & 1924-2007 & 53 & {$[39,81]$} & Zika virus (ZIKV) & {$[22]$} \\
\hline & & & & Chikungunya virus (CHIKV) & [146] \\
\hline & & & & Japanese Encephalitis (JEV) & [101] \\
\hline & & & & Rift Valley fever virus (RVFV) & {$[97,139]$} \\
\hline & & & & West Nile virus (WNV) & [21] \\
\hline \multirow[t]{6}{*}{ Cx. pipiens } & 1916-2013 & 257 & {$[8,56]$} & Tahyna virus (TAHV) & {$[98]$} \\
\hline & & & & Japanese Encephalitis virus (JEV) & [127] \\
\hline & & & & Rift Valley fever virus (RVFV) & [5] \\
\hline & & & & Sindbis virus (SINV) & [99] \\
\hline & & & & Usutu virus (USUV) & {$[36]$} \\
\hline & & & & West Nile virus (WNV) & [106] \\
\hline
\end{tabular}

and S2 file) using Pearson's correlation function available in ENMTools package under R system [151, 152]. Variables contributing less with higher correlation $(|r|<0.7)$ to the ones of highest contribution were omitted from the prediction [64]. This process was repeated until left with a set of uncorrelated variables that all had a model contribution [84, 93], which were then used for final predictions (Table 3).

\section{Species distribution modeling}

The modeling was carried out using Maxent (Maximum Entropy) software version 3.4.1, which uses an optimization procedure comparing species presence (from occurrence records) with environment characteristics, based on the maximum entropy principle [121]. This machine-learning algorithm, designed to be performed with presence-only record data, has recently gained direct use in various field applications for species distribution modeling, with hundreds of peer-reviewed articles published each year [114]. As the literature recommends, we avoided relying only on the default automatic configuration of Maxent, given increasing debate regarding its use as a black-box, which may not always generate the best results $[126,135]$. For each modeled species, we tested a combination of different features (linear, quadratic, product, threshold, and hinge), regularizations multiplier, and used cross-validation to select the optimal settings (S3 file). The Akaike information criterion (AICc) was used to select the optimal combination (the one with minimal AICc value) using NicheA software version 3.0 [93, 125]. Given the lack of occurrence records in some areas, the lack of detailed information on each species distribution range, and the non-availability of absence data, we created a bias file used to fine-tune background and occurrence point selection in Maxent. For this, we restricted background sampling to a maximum radial distance of no more than $5 \mathrm{~km}$ from observation points, using SDMtoolbox [29]. We ran 20 replicates in Maxent for each model and used the mean values to summarize the model predictions results. 
Table 2. Summary of the environmental variables downloaded.

\begin{tabular}{|c|c|c|c|c|c|}
\hline \multirow{2}{*}{$\begin{array}{l}\text { Environmental } \\
\text { variable layers }\end{array}$} & \multirow[t]{2}{*}{ Signification } & \multirow[t]{2}{*}{ Units } & \multicolumn{2}{|c|}{ Resolution } & \multirow[t]{2}{*}{ Reference } \\
\hline & & & Spatial $(\mathrm{km})$ & Temporal & \\
\hline Altitude & Elevation above sea level & $\mathrm{m}$ & $\sim 1 \times 1$ & - & WorldClim $^{\mathrm{a}}$ \\
\hline BIO1 & Annual mean temperature & ${ }^{\circ} \mathrm{C}$ & $\sim 1 \times 1$ & Monthly, 1950-2000 & WorldClim \\
\hline $\mathrm{BIO} 2$ & $\begin{array}{l}\text { Mean diurnal range (mean of monthly } \\
(\max \text { temp - min temp)) }\end{array}$ & ${ }^{\circ} \mathrm{C}$ & $\sim 1 \times 1$ & Monthly, 1950-2000 & WorldClim \\
\hline $\mathrm{BIO} 3$ & Isothermality $(\mathrm{BIO} / \mathrm{BIO})(\times 100)$ & $\%$ & $\sim 1 \times 1$ & Monthly, 1950-2000 & WorldClim \\
\hline $\mathrm{BIO} 4$ & Temperature seasonality (standard deviation $\times 100$ ) & $\%$ & $\sim 1 \times 1$ & Monthly, 1950-2000 & WorldClim \\
\hline $\mathrm{BIO5}$ & Max temperature of warmest month & ${ }^{\circ} \mathrm{C}$ & $\sim 1 \times 1$ & Monthly, 1950-2000 & WorldClim \\
\hline BIO6 & Min temperature of coldest month & ${ }^{\circ} \mathrm{C}$ & $\sim 1 \times 1$ & Monthly, 1950-2000 & WorldClim \\
\hline $\mathrm{BIO} 7$ & Temperature annual range (BIO5-BIO6) & ${ }^{\circ} \mathrm{C}$ & $\sim 1 \times 1$ & Monthly, 1950-2000 & WorldClim \\
\hline $\mathrm{BIO} 8$ & Mean temperature of wettest quarter & ${ }^{\circ} \mathrm{C}$ & $\sim 1 \times 1 \mathrm{~km}$ & Monthly, 1950-2000 & WorldClim \\
\hline BIO9 & Mean temperature of driest quarter & ${ }^{\circ} \mathrm{C}$ & $\sim 1 \times 1$ & Monthly, 1950-2000 & WorldClim \\
\hline $\mathrm{BIO} 10$ & Mean temperature of warmest quarter & ${ }^{\circ} \mathrm{C}$ & $\sim 1 \times 1$ & Monthly, 1950-2000 & WorldClim \\
\hline BIO11 & Mean temperature of coldest quarter & ${ }^{\circ} \mathrm{C}$ & $\sim 1 \times 1$ & Monthly, 1950-2000 & WorldClim \\
\hline $\mathrm{BIO} 12$ & Annual precipitation & $\mathrm{mm}$ & $\sim 1 \times 1$ & Monthly, 1950-2000 & WorldClim \\
\hline $\mathrm{BIO} 13$ & Precipitation of wettest month & $\mathrm{mm}$ & $\sim 1 \times 1$ & Monthly, 1950-2000 & WorldClim \\
\hline BIO14 & Precipitation of driest month & $\mathrm{mm}$ & $\sim 1 \times 1$ & Monthly, 1950-2000 & WorldClim \\
\hline $\mathrm{BIO} 15$ & Precipitation seasonality (coefficient of variation) & $\%$ & $\sim 1 \times 1$ & Monthly, 1950-2000 & WorldClim \\
\hline BIO16 & Precipitation of wettest quarter & $\mathrm{mm}$ & $\sim 1 \times 1$ & Monthly, $1950-2000$ & WorldClim \\
\hline $\mathrm{BIO} 17$ & Precipitation of driest quarter & $\mathrm{mm}$ & $\sim 1 \times 1$ & Monthly, 1950-2000 & WorldClim \\
\hline $\mathrm{BIO} 18$ & Precipitation of warmest quarter & $\mathrm{mm}$ & $\sim 1 \times 1$ & Monthly, 1950-2000 & WorldClim \\
\hline BIO19 & Precipitation of coldest quarter & $\mathrm{mm}$ & $\sim 1 \times 1$ & Monthly, $1950-2000$ & WorldClim \\
\hline
\end{tabular}

${ }^{\mathrm{a}} \mathrm{http} / / /$ www.diva-gis.org/climate.

Table 3. Correlation matrix of the bioclimatic variables retained for prediction.

\begin{tabular}{lcccc}
\hline & BIO1 & BIO10 & BIO11 & BIO12 \\
\hline BIO1 & 1 & 0.225 & 0.248 & 0.520 \\
BIO10 & 0.225 & 1 & 0.375 & -0.200 \\
BIO11 & 0.248 & 0.375 & 1 & 0.242 \\
BIO12 & 0.520 & -0.200 & 0.242 & 1 \\
\hline
\end{tabular}

\section{Modeling evaluation}

Model performance was evaluated using the partial receiver operating characteristic (pROC) approach, in addition to the area under the curve (AUC). Partial ROC represents a more suitable indicator of statistical significance and allows a better assessment of the niche model predictive ability [120], considering only omission error and proportional area predicted as suitable, and only over a range of omission error deemed acceptable in light of error characteristics of the input data [136]. AUC measures can be misleading and may reflect model accuracy poorly. It weights omission and commission errors equally, does not give information about the spatial distribution of model errors, and summarizes the entire ROC curve, including regions that frequently are not relevant to practical applications $[94,100]$. In a partial ROC test, the statistical significance is determined by bootstrap resampling of $50 \%$ of testing data, and probabilities are assessed by direct count of the proportion of bootstrap replicates for which the AUC ratio is $\leq 1.0$ [42]. Occurrence datasets and obtained maps were subjected to over 1000 bootstrap iteration analyses, each based on $50 \%$ random points resampling, with replacement, and with an omission error threshold of $1 \%(p<0.01)$. The pROC statistics test was used using the pROC function available in the NicheToolBox package under R system [118].

\section{Results}

\section{Modeled habitat suitability}

According to AUC measurement (Table 4), all generated models performed well with AUC values exceeding 0.9 (average over 20 runs) and performed significantly better than random expectations based on the partial ROC test $(p<0.01)$. Maxent predicted widespread environmental suitability for Ae. aegypti (Fig. 1 and S4 file) and Ae. vexans (Fig. 2, and S5 file) across the country. Areas with the highest risk of potential distribution are essentially located in central parts. Aedes albopictus probable risk of occurrence (Fig. 3, S6 file, and S7 file) seems to be highly relevant in areas of the northwest, while the rest of the country was found to be probably unsuitable for establishment. The environmental conditions in Morocco (up to half of the country's surface area) seem to fit the potential distribution requirement of Ae. caspius (Fig. 4 and S8 file) and Cx. Pipiens (Fig. 5 and S9 file). Areas classified as highly suitable were primarily located in the center and the northern parts. Moroccan littorals, especially in the north, were modeled at high risk of Ae. detritus probable spreading (Fig. 6 and S10 file). For Ae. vittatus, the environmental conditions in Morocco seem to be currently unsuitable for potential distribution of this species (Fig. 7, S11 file and S12 file). 
Table 4. Area under the curve (AUC) values and partial receiver operating characteristic (pROC) ratios summarizing the performance of ecological niche models (average over 20 runs).

\begin{tabular}{|c|c|c|c|c|c|c|c|}
\hline \multirow[t]{2}{*}{ Species } & \multirow[t]{2}{*}{ Mean AUC* } & \multirow[t]{2}{*}{ Bootstrap iterations } & \multicolumn{5}{|c|}{ pROC ratio } \\
\hline & & & Minimum & Maximum & Mean & Median & $p<0.01$ \\
\hline Ae. aegypti & $0.924 \pm 0.035$ & 1000 & 1.77 & 2.00 & 1.88 & 1.87 & $0 * * *$ \\
\hline Ae. albopictus & $0.961 \pm 0.002$ & 1000 & 1.89 & 1.94 & 1.92 & 1.92 & $0 * * *$ \\
\hline Ae. vexans & $0.945 \pm 0.023$ & 1000 & 1.81 & 2.00 & 1.90 & 1.90 & $0 * * *$ \\
\hline Ae. vittatus & $0.951 \pm 0.013$ & 1000 & 1.74 & 1.75 & 1.74 & 1.74 & $0 * * *$ \\
\hline Ae. caspius & $0.988 \pm 0.006$ & 1000 & 1.64 & 1.88 & 1.68 & 1.65 & $0 * * *$ \\
\hline Ae. detritus & $0.993 \pm 0.003$ & 1000 & 1.75 & 1.96 & 1.80 & 1.76 & $0 * * *$ \\
\hline Cx. pipiens & $0.984 \pm 0.001$ & 1000 & 1.41 & 1.70 & 1.60 & 1.62 & $0 * * *$ \\
\hline
\end{tabular}

* 0.5 (random) $<$ AUC $<1$ (perfect).

**** Highly significant.

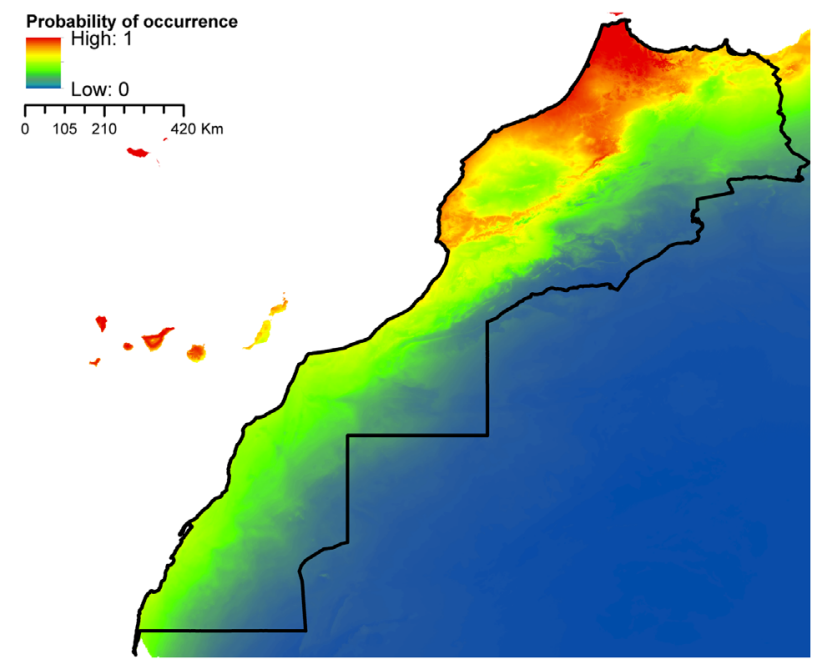

Figure 1. Predicted probability of Ae. aegypti occurrence in Morocco.

\section{Variable importance}

By investigating the relative contribution of the bioclimatic variables used, we were able to identify which of the variables most influences the predictions (Table 5). The mean temperature of the coldest quarter (BIO11) was the most informed variable for Ae. detritus, Ae. caspius and Cx. pipiens potential distribution, followed by the annual mean temperature (BIO1) as the second most contributing. In the case of Ae. vittatus and Ae. aegypti, BIO1 appears to provide the most useful information contributing with $43.9 \%$ and $47.4 \%$, respectively. Concerning Ae. albopictus and Ae. vexans potential prediction, the mean temperature of the warmest quarter (BIO10) was yielded as the most dependent variable.

\section{The one-variable response curves}

The one-variable response curve generated by Maxent is a powerful tool that helps define the modeled habitat suitability requirement for the species considered, depending on only one variable each time (Fig. 8). In terms of successful establishment thresholds, Ae. aegypti is modeled to find suitable conditions in areas where the annual mean temperature is below

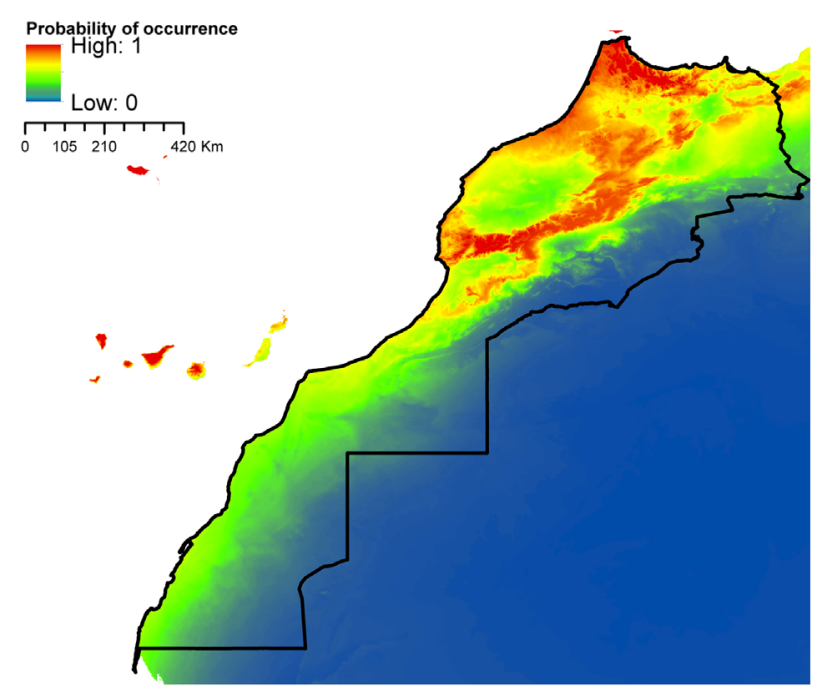

Figure 2. Predicted probability of Ae. vexans occurrence in Morocco.

$25^{\circ} \mathrm{C}$ (optimum from $5{ }^{\circ} \mathrm{C}$ to $10{ }^{\circ} \mathrm{C}$ ) with annual precipitation of at least $200 \mathrm{~mm}$ (optimum $<600 \mathrm{~mm}$ ). A similar amount of precipitation with a mean temperature of the warmest quarter of no more than $25^{\circ} \mathrm{C}$ (optimum from $10^{\circ} \mathrm{C}$ to $17^{\circ} \mathrm{C}$ ) seems necessary for successful establishment of Ae. vexans in the country. In the case of Ae. albopictus, areas with mean temperature of the warmest quarter ranging from $17^{\circ} \mathrm{C}$ to $27^{\circ} \mathrm{C}$ and annual mean temperature of $11-20^{\circ} \mathrm{C}$ were modeled as suitable. Aedes vittatus is modeled to be potentially present in regions with an annual mean temperature and a mean temperature of the coldest quarter ranging from $20{ }^{\circ} \mathrm{C}$ to $30{ }^{\circ} \mathrm{C}$. For Ae. detritus, Ae. caspius and $C x$. Pipiens predicted distribution, it seems to highly depend on mean temperature of the coldest quarter and annual mean temperature ranging from $10^{\circ} \mathrm{C}$ to $20^{\circ} \mathrm{C}$.

\section{Discussion}

In the present study, we generated prediction models for the potential distribution of the well-known disease vectors Ae. aegypti, Ae. vexans, Ae. caspius, Ae. detritus, and $C x$. pipiens in Morocco. Also, we estimated and evaluated the habitat suitability for the potential occurrence and establishment 


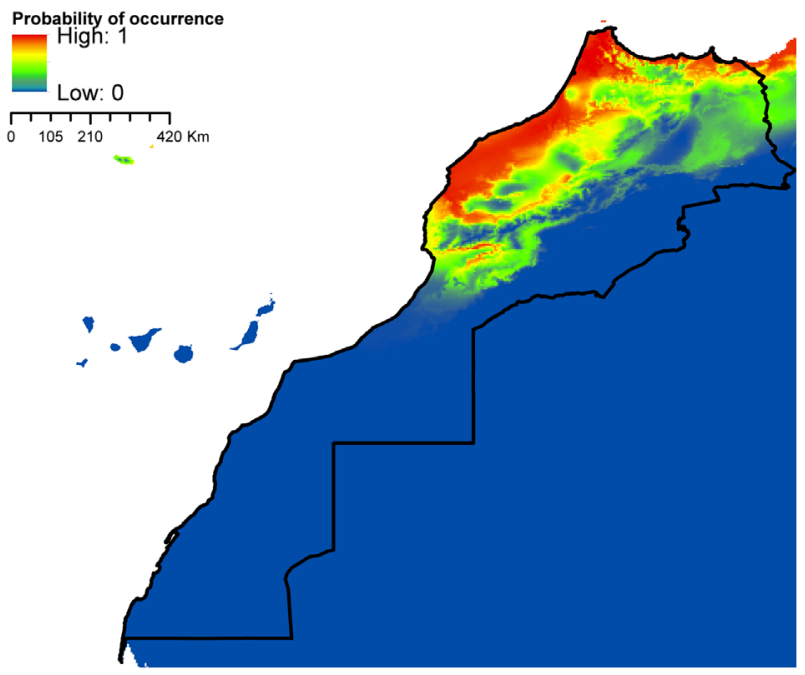

Figure 3. Predicted probability of Ae. albopictus occurrence in Morocco.

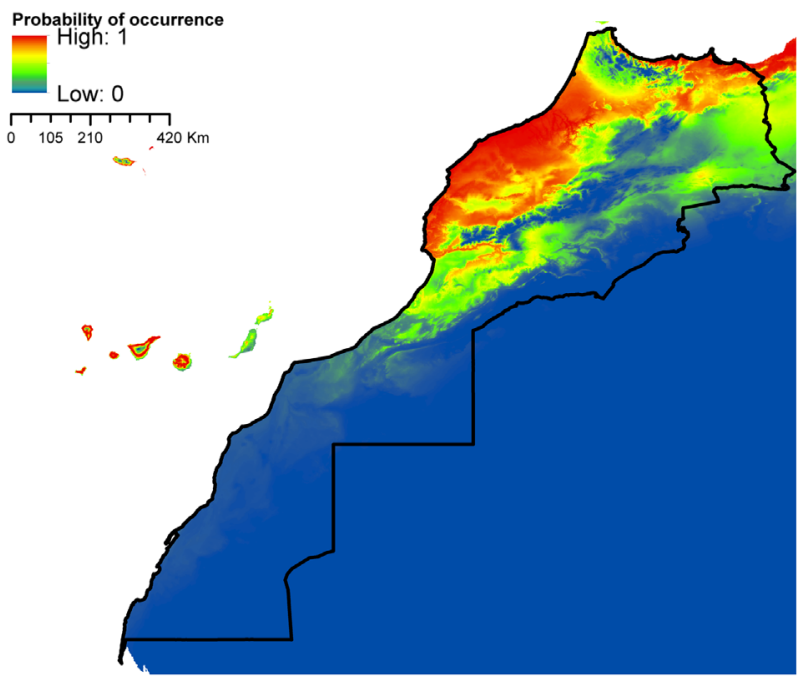

Figure 4. Predicted distribution of Ae. caspius in Morocco.

of Ae. albopictus and Ae. vittatus, recorded only once in the country.

Knowledge of the current distribution of these mosquito species can be of great value in identifying the areas at risk of probable associated arboviruses expansion. Specifically, the habitat suitability map generated herein can help predict where these species could become established. Also, to focus attention on areas where surveillance could be prioritized, especially where entomological reporting remains poor or where the vector is currently present but has yet to fulfill its potential fundamental niche.

With the exception of Ae. vittatus, a species in which the current environmental conditions in the country were modeled unsuitable, the north and central parts of Morocco appeared to be the areas at high risk. Importantly, they were modeled suitable for six species out of seven (Ae. aegypti, Ae. vexans, Ae. caspius, Cx. pipiens, Ae. detritus, and Ae. albopictus). For the southern parts, it seems that conditions might be currently suitable for potential distribution of only Ae. aegypti and Ae. vexans.

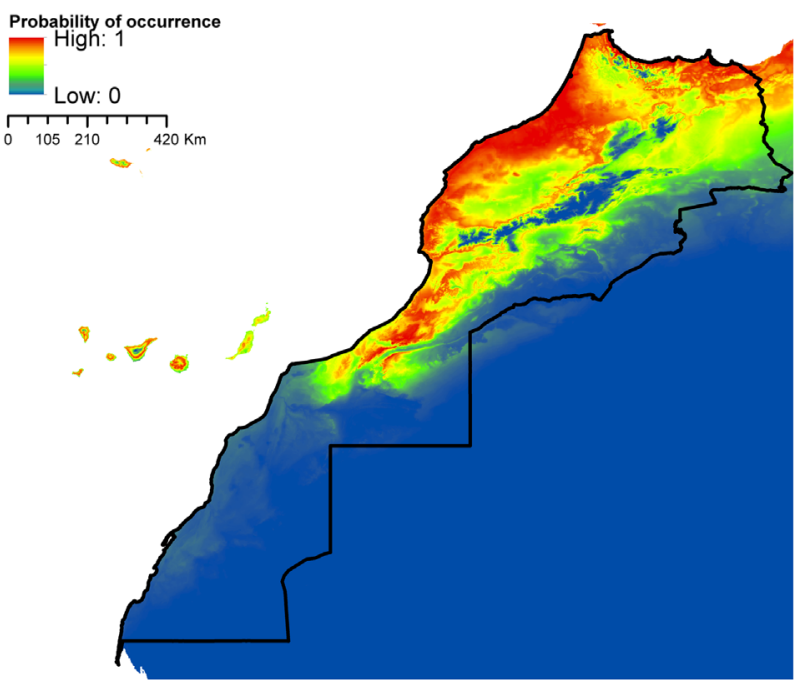

Figure 5. Predicted distribution of Cx. pipiens in Morocco.

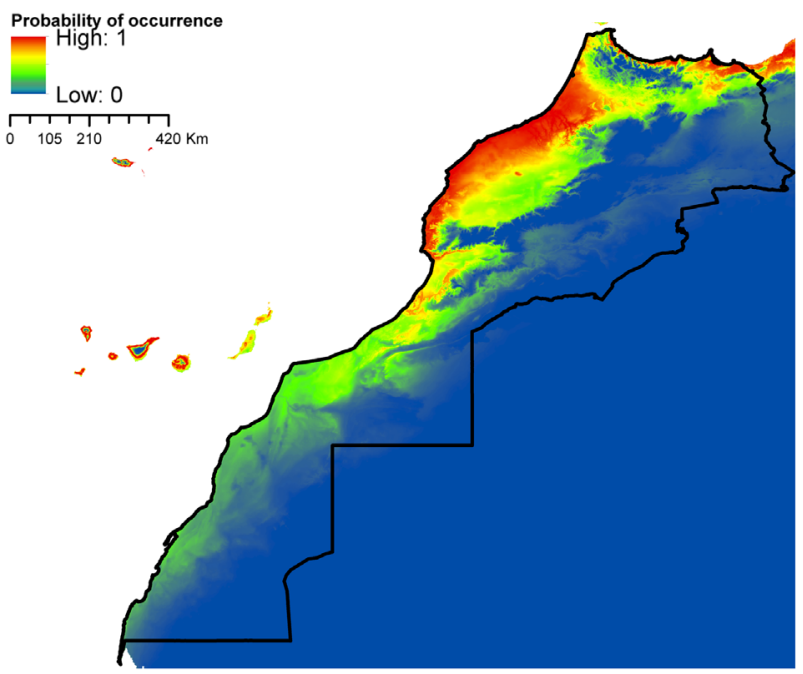

Figure 6. Predicted distribution of Ae. detritus in Morocco.

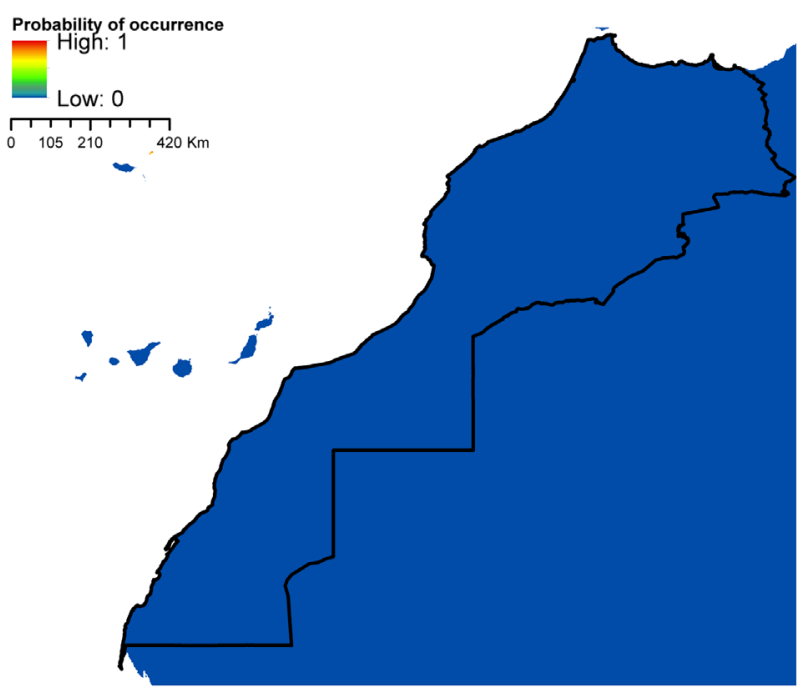

Figure 7. Predicted probability of Ae. vittatus occurrence in Morocco. 
Table 5. Main contribution of the environmental variables used for modeling.

\begin{tabular}{lccccccc}
\hline Environmental variable layers & \multicolumn{5}{c}{ Permutation importance (\%) } \\
\cline { 2 - 7 } & Ae. aegypti & Ae. albopictus & Ae. vexans & Ae. vittatus & Ae. detritus & Ae. caspius & Cx. pipiens \\
\hline Annual mean temperature (BIO1) & 43.9 & 25 & 4.2 & 47.4 & 20.6 & 29.2 & 35 \\
Mean temperature of warmest quarter (BIO10) & 17.9 & 31.2 & 76.6 & 9.3 & 9.3 & 7.3 & 15.6 \\
Mean temperature of coldest quarter (BIO11) & 1.8 & 23.3 & 3.5 & 35.1 & 67.5 & 49.8 & 47.6 \\
Annual precipitation (BIO12) & 36.3 & 20.6 & 15.6 & 8.2 & 2.5 & 13.7 & 1.8 \\
\hline
\end{tabular}

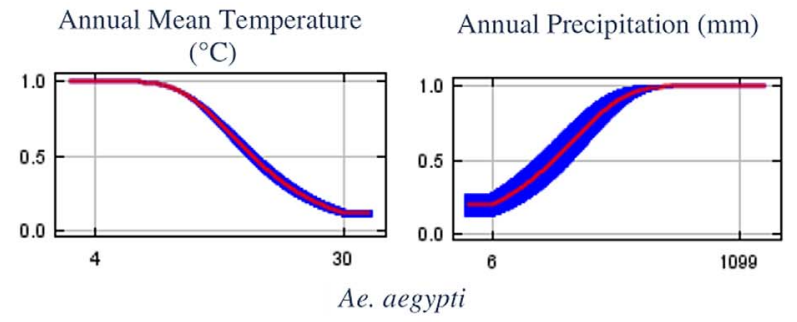

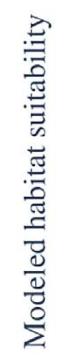
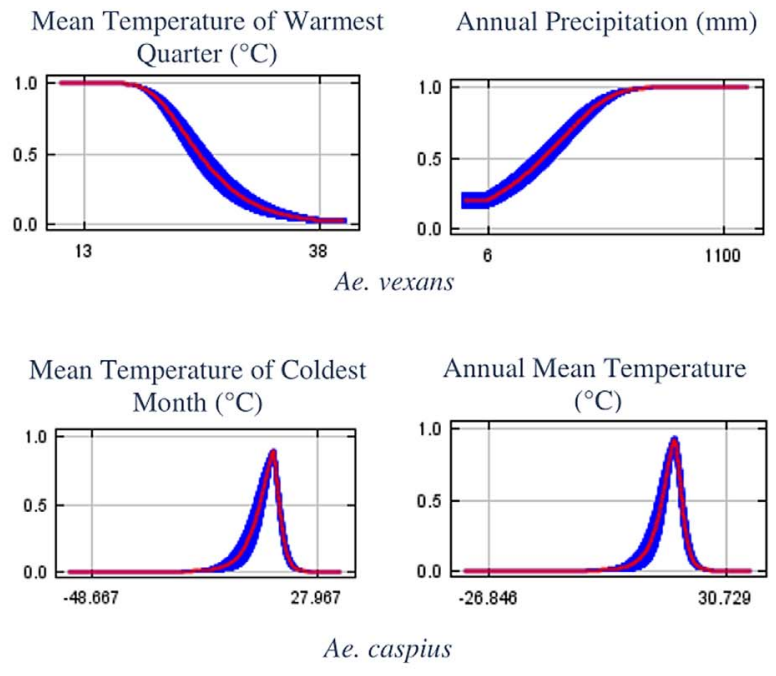

Ae. caspius

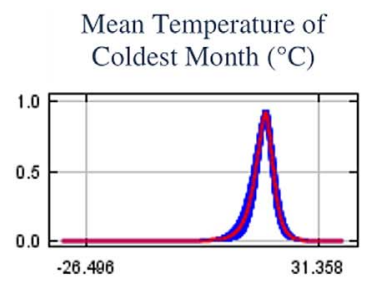

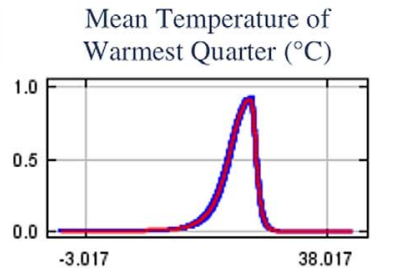
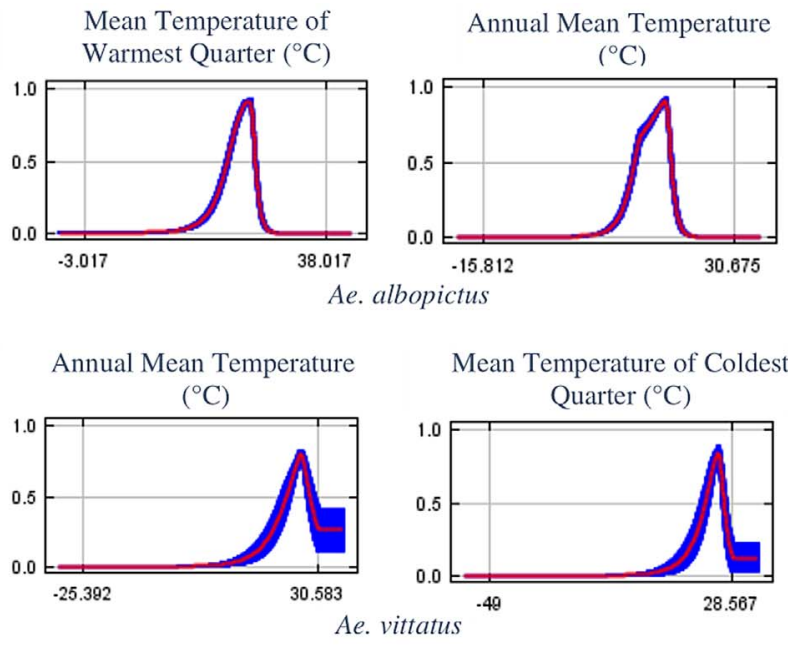

Mean Temperature of Coldest Quarter $\left({ }^{\circ} \mathrm{C}\right)$

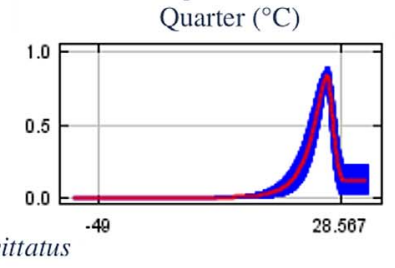

Mean Temperature of Coldest Month $\left({ }^{\circ} \mathrm{C}\right)$

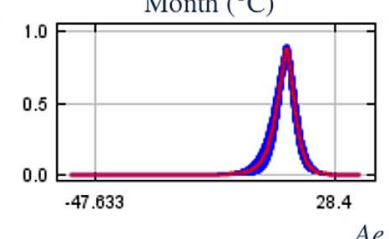

Annual Mean Temperature

$\left({ }^{\circ} \mathrm{C}\right)$

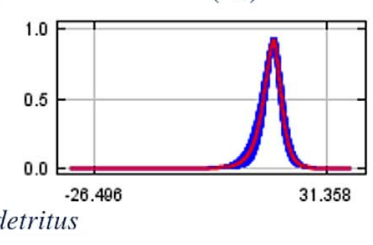

Annual Mean Temperature

$\left({ }^{\circ} \mathrm{C}\right)$

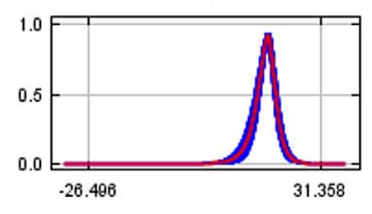

Cx. pipiens

Figure 8. Response curves (for most contributing variables) for the one-variable-models indicating the environmental limits for each vector.

Overall, the risk of establishment of mosquitoes in the country can be classified into two main categories: species with high (Ae. aegypti, Ae. vexans, Cx. pipiens, Ae. caspius, Ae. detritus, and Ae. albopictus) and low (Ae. vittatus) probability of establishment. This difference in their potential distribution may reflect unique environmental requirements for each species such as larval habitat.

The minimum temperature or the mean temperature of the coldest quarter were identified as critical factors determining the presence of Ae. aegypti in multiple studies [52, 87].
Temperatures ranging from $4{ }^{\circ} \mathrm{C}$ to $10{ }^{\circ} \mathrm{C}$ were estimated to be the minimum temperature threshold for Ae. aegypti [143]. This is consistent with our findings as Maxent predicted suitable conditions in areas where the annual mean temperature is below $25{ }^{\circ} \mathrm{C}$. It is worth mentioning here that the model developed for Ae. aegypti (Ae. vexans as well) using small sample sizes should be interpreted with caution as the prediction only identifies regions that have similar environmental conditions to the points used, and do not represent actual limits to the range of the species [119]. For example, Ae. aegypti was 
modeled to find suitable conditions in areas where the annual mean temperature is below $25{ }^{\circ} \mathrm{C}$ (optimum from $5{ }^{\circ} \mathrm{C}$ to $10{ }^{\circ} \mathrm{C}$ ), according to the one-variable response curve generated by Maxent, an optimum which seems very low for a largely non-temperate species. Aedes aegypti is usually known to be tolerant to high temperatures and can be viable following exposure to temperatures up to $40{ }^{\circ} \mathrm{C}$ [27], but cannot resist low temperatures. Larval survival requires a temperature higher than $10{ }^{\circ} \mathrm{C}[144]$ and prolonged exposure of eggs to temperatures below $10{ }^{\circ} \mathrm{C}$ has been fatal [40].

According to our prediction results, Ae. albopictus was modeled to find suitable conditions in areas with a mean temperature of the warmest quarter ranging from $17{ }^{\circ} \mathrm{C}$ to $27^{\circ} \mathrm{C}$ and annual mean temperature of $11-20^{\circ} \mathrm{C}$. This is completely in accordance with the commonly known environmental limits announced by the European Centre for Disease Prevention and Control (ECDC), regarding the successful establishment thresholds of this species in Europe. According to their findings, Ae. albopictus could occur in locations where the mean annual temperature exceeds $1{ }^{\circ} \mathrm{C}$ (required condition for mosquito activity and survival), a summer temperature of $25-30{ }^{\circ} \mathrm{C}$, mean temperature of the coldest quarter $>0{ }^{\circ} \mathrm{C}$, and annual rainfall of at least $500 \mathrm{~mm}$ (pre-requisite for aquatic habitats availability and maintenance). However, reports also indicated that this species can successfully establish under lower mean temperatures $\left(5-28.5{ }^{\circ} \mathrm{C}\right)$ and annual precipitation not exceeding $290 \mathrm{~mm}[54,108]$.

Kraemer et al. [88] and Kamal et al. [85] were the first to predict the global potential distribution of Ae. aegypti and Ae. albopictus using ecological niche modeling. Accordingly, the northwest Atlantic coast of the country was predicted at-risk of Ae. aegypti and Ae. albopictus potential distribution, which is consistent with our results. It is worth mentioning here that in both studies no points were included from Morocco or North Africa. In addition, our study placed other areas at risk of Ae. aegypti distribution including southwestern Morocco where no previous observed occurrence records were available. Either the species exists here but is not yet documented or it is currently absent but the environmental conditions are suitable for possible introduction in the future. Either way, these areas are worth being intensively monitored as soon as possible, especially after the species has recently emerged in North Mauritania and Egypt, after years of presumed absence [3, 113]. Of note, the areas where the species was notified, in North Mauritania and Egypt, share similar environmental conditions with southern Morocco, according to the Köppen-Geiger Climate Classification [14].

Aedes caspius, Cx. pipiens and Ae. detritus predicted distribution in Morocco seems to highly depend on the mean temperature of the coldest quarter and annual mean temperature ranging from 10 to $20^{\circ} \mathrm{C}$. In Roiz et al. [132], a study evaluating climatic effects on mosquito abundance in Mediterranean wetlands using long-term series of mosquito abundance data (2003-2012), the mean temperature was positively related to Cx. pipiens and Ochlerotatus caspius (Ae. caspius) abundances. Also, Ewing et al. [60] demonstrated that increases in mean annual temperature and amplitude of seasonal temperature fluctuations will increase the abundance of temperate mosquitoes $(C x$. pipiens $)$ in the United Kingdom in the coming years.
Aedes caspius potential distribution showed high suitability across the northwestern and northeastern sides of the country, essentially at low altitudes. Aedes caspius is a species with a very wide Palearctic distribution; it stretches from Europe to central Asia, and from Egypt to Morocco [55, 130]. It is a very well-represented species in the Mediterranean Basin, mainly along the coast; it has been reported in Italy [147], Belgium [26], France [13, 37], and Spain [73]. In Morocco, the species was mainly collected in coastal and relatively more humid regions. Suitable habitats for Ae. detritus are currently limited to the northwestern part of the country, especially along the coastline. Indeed, the species showed a similar distribution pattern in Europe as it is found all over the European coastlines, e.g. in the United Kingdom [23], Italy [104], Belgium [26], France [28], and Spain [133]. It is a common Palearctic species that is more abundant in southern and dry regions [15]. In North Africa, the species has been detected in Egypt [1], Tunisia [16], Algeria [111], etc. In Morocco Ae. detritus is very well represented on the littoral zones, where it is found on a fairly regular strip from Tangier to Tantan (the Atlantic coast), and on a less regular strip from Tangier to Saïdia (the Mediterranean coast) [140]. According to our model predictions, up to half of the country's surface area seems to be suitable for $C x$. pipiens potential distribution. Areas classified as highly suitable were primarily located in the central and the northern parts. Culex pipiens is a very common and ubiquitous species in Morocco, [2, 20]. In temperate regions, particularly in the Mediterranean basin, $C x$. pipiens is recognized as one of the most widespread cosmopolitan species $[5,30]$. The species also dwells in the temperate regions of Africa, Asia, Australia, Europe, North and South America [80].

Versteirt et al. [148] previously identified the current geographic distribution of Ae. caspius, Ae. detritus and Cx. pipiens in Europe and countries surrounding the Mediterranean Basin, including Morocco. According to their findings, Ae. caspius and Ae. detritus are predicted with high probability on the Atlantic coast of Morocco. By contrast, Cx. pipiens was predicted to be highly distributed in areas with more temperate climatic conditions such as the Mediterranean Sea coastline north of Morocco. Our models yielded similar results of habitat suitability for Ae. caspius and Ae. detritus on the Atlantic coast and Cx. pipiens on the Mediterranean Sea coastline but recognized different distributional patterns across the rest of the country. Reasons for such disagreement may be essentially the nonappropriate choice of explanatory variables used for prediction in their study: temperature and vegetation, annual amplitude of night time temperature, variance in night time temperature, variance in the enhanced vegetation index, phase of the annual night time temperature cycle, and maximum of the enhanced vegetation index, which resulted in substantial underestimation of habitat suitability. It is known that temperature and precipitation are the most important factors that condition mosquito survival and distribution, and predictions built with these variables usually produce more realistic results [31, 46, 82, 85, 88].

Aedes vexans is considered a nuisance species in central Europe and the Mediterranean region [19]. The species is also indigenous to North America as it is found throughout the United States and southern Canada [115]. In North Africa, the species has been detected in Mauritania, Algeria, Tunisia, and Morocco [140, 141]. 
Versteirt et al. [148] also identified the current geographic distribution of Ae. vexans in Europe and the Mediterranean Basin. Accordingly, Ae. vexans is predicted with a very low probability in Morocco. Our model prediction yielded different results of habitat suitability. Reasons for such disagreement may be the non-appropriate choice of explanatory variables used for prediction in their study (as previously discussed), and also the absence of points used from Morocco or other north African countries.

The current distribution of Ae. vittatus includes tropical and subtropical areas in Asia and Africa. In Europe, the species is restricted to the occidental Mediterranean region comprising Italy, France, Spain, and Portugal [53, 138].

Giving the potential suitability of the country for the occurrence and distribution of Arboviruses vectors, there is an urgent need to undertake and enhance periodic surveillance campaigns in areas currently considered at high risk. This is particularly important as it was demonstrated recently that Ae. albopictus identified in Rabat in 2016 [17] is competent for not only Zika virus transmission but also for many Arboviruses: Dengue, Chikungunya, and Yellow fever viruses [4]. Moreover, multiple cases of some imported arboviruses have been described recently in Morocco, especially Dengue [11] and Chikungunya [12]. With a suitable environment, viremic travelers caring viruses, and the potential wild distribution of known competent vectors, all key elements for potential outbreaks are present.

However, we cannot deny that there are some limits surrounding our study, as the case with every study forecasting habitat suitability or the potential distribution of any living species (Ogden 2017). Specifically, the models emphasize climate (e.g. macroclimate) as the key driver of mosquito distributions. The suitable habitats are modeled based on the assumption that there will not be any dispersed limitation encountered by the species. The impact of biological interactions, such as the presence of potential competitors or predators in the new predicted habitats, is also neglected in our models. Therefore, our prediction is an ideal state and should be considered as a starting point to target and enhance surveillance efforts in areas identified as high risk.

\section{Supplementary materials}

Supplementary material is available at https://www. parasite-journal.org/10.1051/parasite/2021030/olm

S1 File. Correlation matrix results of the environmental variables collinearity test.

S2 File. Correlation matrix Heatmap.

S3 File. Evaluation metrics of the Maxent model runs using different parameters and combinations.

S4 File. Ae. aegypti prediction model with occurrence points.

S5 File. Ae. vexans prediction model with occurrence points.

S6 File. Modeling results for Ae. albopictus in Mediterranean Basin countries.

S7 File. Ae. albopictus prediction model with occurrence points.

S8 File. Ae. caspius prediction model with occurrence points.
S9 File. Cx. pipiens prediction model with occurrence points.

S10 File. Ae. detritus prediction model with occurrence points.

S11 File. Global potential distribution of Ae. vittatus.

S12 File. Ae. vittatus prediction model with occurrence points.

Acknowledgements. This study was supported by Cadi Ayyad University, Faculty of Medicine and Pharmacy, Department of Medical Biology, Marrakech-Morocco. The authors would like to thank the Health Delegation and Health Officers of Marrakech and Al Haouz province for their expertise and technical support.

\section{Funding}

This research did not receive any specific grant from funding agencies in the public, commercial, or not-for-profit sectors.

\section{Conflict of interest}

The authors declare that they have no competing interests.

\section{References}

1. Abdel-Hamid YM, Soliman MI, Kenawy MA. 2011. Mosquitoes (Diptera: Culicidae) in relation to the risk of disease transmission in El Ismailia Governorate, Egypt. Journal of the Egyptian Society of Parasitology, 41(2), 347-356.

2. Aboulfadl S, Mellouki F, Aouinty B, Faraj C. 2020. Susceptibility status of Culex pipiens larvae (Diptera: Culicidae) to the main insecticides used in larval control in the regions of Rabat and Casablanca in Morocco. International Journal of Pest Management, 1-7.

3. Abozeid S, Elsayed AK, Schaffner F, Samy AM. 2018. Re-emergence of Aedes aegypti in Egypt. Lancet Infectious Diseases, 18(2), 142-143.

4. Amraoui F, Ben Ayed W, Madec Y, Faraj C, Himmi O, Btissam A, Sarih M, Failloux AB. 2019. Potential of Aedes albopictus to cause the emergence of arboviruses in Morocco. PLoS Neglected Tropical Diseases, 13(2), e0006997.

5. Amraoui F, Krida G, Bouattour A, Rhim A, Daaboub J, Harrat Z, Boubidi SC, Tijane M, Sarih M, Failloux AB. 2012. Culex pipiens, an experimental efficient vector of West Nile and Rift Valley fever viruses in the Maghreb region. PLoS One, 7(5), e36757.

6. Amraoui F, Pain A, Piorkowski G, Vazeille M, Couto-Lima D, de Lamballerie X, Lourenco-de-Oliveira R, Failloux AB. 2018. Experimental adaptation of the Yellow Fever Virus to the mosquito Aedes albopictus and potential risk of urban epidemics in Brazil, South America. Scientific Reports, 8(1), 14337.

7. Amraoui F, Vazeille M, Failloux AB. 2016. French Aedes albopictus are able to transmit yellow fever virus. Eurosurveillance, 21(39), 30361.

8. Anfreville L. 1916. Les Moustiques de Salé (Maroc). Bulletin de la Société de Pathologie Exotique, 9, 140-142.

9. Apodaca-Medina AI, Torres-Avendano JI, Rendon-Maldonado JG, Torres-Montoya EH, Flores-Lopez BA, Del Angel RM, Velarde-Felix JS, Salomon-Soto VM, Castillo-Ureta H. 2018. First evidence of vertical infection of Dengue virus 2 in Aedes 
aegypti mosquitoes from Sinaloa, Mexico. Vector-Borne and Zoonotic Diseases, 18(4), 231-233.

10. Bailly CH. 1973. Etude préliminaire d'une récolte d'Anopheles labranchae par piège C.D.C réalisée dans la région de Larache, Maroc. Bulletin de l'Organisation Mondiale de la Santé, 49, 49-55.

11. Bajjou T, Akhouad Y, Hilali F, Elkochri S, Laraqui A, Touil N, Lahlou Amine I, Mahassine F, Sekhsokh Y. 2018. Dengue fever in Morocco: result of surveillance during the year 2017 and first imported cases. International Journal of Research in Medical Sciences, 6(3), 1029.

12. Bajjou T, Reggad A, Hilali F, Elkochri S, Laraqui A, Touil N, Lahlou Amine I, Sekhsokh Y, Mahassine F. 2017. Chikungunya infection confirmed in a Moroccan traveller returning from Bangladesh. International Journal of Research in Medical Sciences, 6(1), 343.

13. Balenghien T, Vazeille M, Grandadam M, Schaffner F, Zeller H, Reiter P, Sabatier P, Fouque F, Bicout DJ. 2008. Vector competence of some French Culex and Aedes mosquitoes for West Nile Virus. Vector-Borne and Zoonotic Diseases, 8(5), 589-596.

14. Beck HE, Zimmermann NE, McVicar TR, Vergopolan N, Berg A, Wood EF. 2018. Present and future Köppen-Geiger climate classification maps at $1-\mathrm{km}$ resolution. Scientific Data, 5, 180214.

15. Becker N, Petrj D, Zgomba M, Boase C, Madon M, Dahl C, Kaiser A. 2020. Mosquitoes and their control, 3 edn. Springer. p. 587.

16. Ben Ayed W, Amraoui F, M'Ghirbi Y, Schaffner F, Rhaim A, Failloux AB, Bouattour A. 2019. A survey of Aedes (Diptera: Culicidae) Mosquitoes in Tunisia and the potential role of Aedes detritus and Aedes caspius in the transmission of Zika Virus. Journal of Medical Entomology, 56(5), 1377-1383.

17. Bennouna A, Balenghien T, El Rhaffouli H, Schaffner F, Garros C, Gardes L, Lhor Y, Hammoumi S, Chlyeh G, Fassi Fihri O. 2017. First record of Stegomyia albopicta (= Aedes albopictus) in Morocco: a major threat to public health in North Africa? Medical and Veterinary Entomology, 31(1), 102-106.

18. Bhatt S, Gething PW, Brady OJ, Messina JP, Farlow AW, Moyes CL, Drake JM, Brownstein JS, Hoen AG, Sankoh O, Myers MF, George DB, Jaenisch T, Wint GR, Simmons CP, Scott TW, Farrar JJ, Hay SI. 2013. The global distribution and burden of dengue. Nature, 496(7446), 504-507.

19. Birnberg L, Talavera S, Aranda C, Nunez AI, Napp S, Busquets N. 2019. Field-captured Aedes vexans (Meigen, 1830) is a competent vector for Rift Valley fever phlebovirus in Europe. Parasites \& Vectors, 12(1), 484.

20. Bkhache M, Tmimi F-Z, Charafeddine O, Faraj C, Failloux A-B, Sarih Mh. 2016. First report of L1014F-kdr mutation in Culex pipiens complex from Morocco. Parasites \& Vectors, 9 (1), 644 .

21. Blagrove MS, Sherlock K, Chapman GE, Impoinvil DE, McCall PJ, Medlock JM, Lycett G, Solomon T, Baylis M. 2016. Evaluation of the vector competence of a native UK mosquito Ochlerotatus detritus (Aedes detritus) for dengue, chikungunya and West Nile viruses. Parasites \& Vectors, 9, 452.

22. Blagrove MSC, Caminade C, Diggle PJ, Patterson EI, Sherlock K, Chapman GE, Hesson J, Metelmann S, McCall PJ, Lycett G, Medlock J, Hughes GL, Torre Ad, Baylis M. 2020. Potential for Zika virus transmission by mosquitoes in temperate climates. Proceedings of the Royal Society B: Biological Sciences, 287(1930), 20200119.

23. Blagrove MSC, Sherlock K, Chapman GE, Impoinvil DE, McCall PJ, Medlock JM, Lycett G, Solomon T, Baylis M.
2016. Evaluation of the vector competence of a native UK mosquito Ochlerotatus detritus (Aedes detritus) for dengue, chikungunya and West Nile viruses. Parasites \& Vectors, 9(1), 452 .

24. Bogoch II, Brady OJ, Kraemer MUG, German M, Creatore MI, Kulkarni MA, Brownstein JS, Mekaru SR, Hay SI, Groot E, Watts A, Khan K. 2016. Anticipating the international spread of Zika virus from Brazil. Lancet, 387(10016), 335336.

25. Bouallam S. 1992. Le paludisme et les moustiques dans la région de Marrakech. Ecologie et cycles biologiques des espèces culicidiennes, Thèse de Doctorat de $3 e$ cycle, Université Cadi Ayyad.

26. Boukraa S, Dekoninck W, Versteirt V, Schaffner F, Coosemans M, Haubruge E, Francis F. 2015. Updated checklist of the mosquitoes (Diptera: Culicidae) of Belgium. Journal of Vector Ecology, 40(2), 398-407.

27. Brady OJ, Johansson MA, Guerra CA, Bhatt S, Golding N, Pigott DM, Delatte H, Grech MG, Leisnham PT, Maciel-deFreitas R, Styer LM, Smith DL, Scott TW, Gething PW, Hay SI. 2013. Modelling adult Aedes aegypti and Aedes albopictus survival at different temperatures in laboratory and field settings. Parasites \& Vectors, 6, 351.

28. Brengues C, Ferré JB, Le Goff G, Lami P, Pratlong F, Pasteur N, Lagneau C, Simard F, Robert V. 2014. A multiplex PCR to differentiate the two sibling species of mosquitoes Ochlerotatus detritus and Oc. coluzzii and evidence for further genetic heterogeneity within the Detritus complex. Infection, Genetics and Evolution, 28, 676-680.

29. Brown JL, Bennett JR, French CM. 2017. SDMtoolbox 2.0: the next generation Python-based GIS toolkit for landscape genetic, biogeographic and species distribution model analyses. PeerJ, 5, e4095.

30. Brugman VA, Hernández-Triana LM, Medlock JM, Fooks AR, Carpenter S, Johnson N. 2018. The role of Culex pipiens L. (Diptera: Culicidae) in virus transmission in Europe. International Journal of Environmental Research and Public Health, 15(2), 389.

31. Brugueras S, Fernández-Martínez B, Martínez-de la Puente J, Figuerola J, Porro TM, Rius C, Larrauri A, Gómez-Barroso D. 2020. Environmental drivers, climate change and emergent diseases transmitted by mosquitoes and their vectors in southern Europe: a systematic review. Environmental Research, 191, 110038.

32. Brustolin M, Santamaria C, Napp S, Verdun M, Rivas R, Pujol N, Talavera S, Busquets N. 2018. Experimental study of the susceptibility of a European Aedes albopictus strain to dengue virus under a simulated Mediterranean temperature regime. Medical and Veterinary Entomology, 32(4), 393-398.

33. Brustolin M, Talavera S, Nunez A, Santamaria C, Rivas R, Pujol N, Valle M, Verdun M, Brun A, Pages N, Busquets N. 2017. Rift valley fever virus and European mosquitoes: vector competence of Culex pipiens and Stegomyia albopicta (= Aedes albopictus). Medical and Veterinary Entomology, 31(4), 365-372.

34. Brustolin M, Talavera S, Santamaria C, Rivas R, Pujol N, Aranda C, Marques E, Valle M, Verdun M, Pages N, Busquets N. 2016. Culex pipiens and Stegomyia albopicta (= Aedes albopictus) populations as vectors for lineage 1 and 2 West Nile virus in Europe. Medical and Veterinary Entomology, 30 (2), 166-173.

35. Bueno-Mari R, Jimenez-Peydro R. 2013. Global change and human vulnerability to vector-borne diseases. Frontiers in Physiology, 4, 158.

36. Calzolari M, Bonilauri P, Bellini R, Albieri A, Defilippo F, Maioli G, Galletti G, Gelati A, Barbieri I, Tamba M, Lelli D, 
Carra E, Cordioli P, Angelini P, Dottori M. 2010. Evidence of simultaneous circulation of West Nile and Usutu viruses in mosquitoes sampled in Emilia-Romagna region (Italy) in 2009. PLoS One, 5(12), e14324.

37. Carron A, Bichaud L, Platz N, Bicout DJ. 2008. Survivorship characteristics of the mosquito Aedes caspius adults from southern France under laboratory conditions. Medical and Veterinary Entomology, 22(1), 70-73.

38. Cevallos V, Ponce P, Waggoner JJ, Pinsky BA, Coloma J, Quiroga C, Morales D, Cardenas MJ. 2018. Zika and Chikungunya virus detection in naturally infected Aedes aegypti in Ecuador. Acta Tropica, 177, 74-80.

39. Charrier H. 1924. Le Stegomyia fasciata dans la région de Tanger (Maroc). Bulletin de la Société de Pathologie Exotique, 17, 137-142.

40. Christophers R. 1960. Aedes aegypti (L.) the yellow fever mosquito: its life history, bionomics and structure. Cambridge, UK: Cambridge University Press.

41. Ciota AT, Bialosuknia SM, Ehrbar DJ, Kramer LD. 2017. Vertical Transmission of Zika Virus by Aedes aegypti and Ae. albopictus Mosquitoes. Emerging Infectious Diseases, 23(5), 880-882.

42. Cobos ME, Peterson AT, Barve N, Osorio-Olvera L. 2019. kuenm: an R package for detailed development of ecological niche models using Maxent. PeerJ, 7, e6281.

43. Conley AK, Fuller DO, Haddad N, Hassan AN, Gad AM, Beier JC. 2014. Modeling the distribution of the West Nile and Rift Valley Fever vector Culex pipiens in arid and semi-arid regions of the Middle East and North Africa. Parasites \& Vectors, 7, 289.

44. Cook CL, Huang YS, Lyons AC, Alto BW, Unlu I, Higgs S, Vanlandingham DL. 2018. North American Culex pipiens and Culex quinquefasciatus are competent vectors for Usutu virus. PLOS Neglected Tropical Diseases, 12(8), e0006732.

45. Costa-da-Silva AL, Ioshino RS, Petersen V, Lima AF, Cunha MDP, Wiley MR, Ladner JT, Prieto K, Palacios G, Costa DD, Suesdek L, Zanotto PMA, Capurro ML. 2017. First report of naturally infected Aedes aegypti with chikungunya virus genotype ECSA in the Americas. PLoS Neglected Tropical Diseases, 11(6), e0005630.

46. Cunze S, Kochmann J, Koch LK, Klimpel S. 2016. Aedes albopictus and its environmental limits in Europe. PLoS One, 11(9), e0162116.

47. da Costa CF, da Silva AV, do Nascimento VA, de Souza VC, Monteiro D, Terrazas WCM, Dos Passos RA, Nascimento S, Lima JBP, Naveca FG. 2018. Evidence of vertical transmission of Zika virus in field-collected eggs of Aedes aegypti in the Brazilian Amazon. PLoS Neglected Tropical Diseases, 12(7), e0006594.

48. de Wispelaere M, Despres P, Choumet V. 2017. European Aedes albopictus and Culex pipiens are competent vectors for Japanese encephalitis virus. PLoS Neglected Tropical Diseases, 11(1), e0005294.

49. Diagne C, Faye O, Guerbois Galla M, Knight R, Diallo D, Faye O, Ba Y, Dia I, Weaver S, Sall AA, Diallo M. 2014. Vector competence of Aedes aegypti and Aedes vittatus (Diptera: Culicidae) from Senegal and Cape Verde Archipelago for West African Lineages of Chikungunya Virus. American Journal of Tropical Medicine and Hygiene, 91(3), 635-641.

50. Diagne CT, Diallo D, Faye O, Ba Y, Faye O, Gaye A, Dia I, Faye O, Weaver SC, Sall AA, Diallo M. 2015. Potential of selected Senegalese Aedes spp. mosquitoes (Diptera: Culicidae) to transmit Zika virus. BMC Infectious Diseases, 15, 492.

51. Diallo D, Sall AA, Diagne CT, Faye O, Faye O, Ba Y, Hanley KA, Buenemann M, Weaver SC, Diallo M. 2014. Zika virus emergence in mosquitoes in southeastern Senegal, 2011. PLoS One, 9(10), e109442.

52. Dickens BL, Sun H, Jit M, Cook AR, Carrasco LR. 2018. Determining environmental and anthropogenic factors which explain the global distribution of Aedes aegypti and Ae. albopictus. BMJ Global Health, 3(4), e000801.

53. Diez-Fernandez A, Martinez-de la Puente J, Ruiz S, GutierrezLopez R, Soriguer R, Figuerola J. 2018. Aedes vittatus in Spain: current distribution, barcoding characterization and potential role as a vector of human diseases. Parasites \& Vectors, 11(1), 297.

54. ECDC. 2016. Aedes albopictus - Factsheet for experts. [cited 17/03/2019]. Available from: https://ecdc.europa.eu/en/disease-vectors/facts/mosquito-factsheets/aedes-albopictus.

55. ECDC. 2020. Aedes caspius - current known distribution: May 2020. Stockholm: ECDC. [cited 2020 01/11]. Available from: Mosquito maps [internet]. Available from: https://ecdc.europa.eu/ en/disease-vectors/surveillance-and-disease-data/mosquito-maps.

56. El Ouali Lalami A, El-Akhal F, El Amri N, Maniar S, Faraj C. 2014. État de la résistance du moustique Culex pipiens vis-àvis du téméphos au centre du Maroc. Bulletin de la Société de Pathologie Exotique, 107, 194-197.

57. El Ouali Lalami A, Hindi T, Azzouzi A, Elghadraoui L, Maniar S, Faraj C, Adlaoui E, Ameur I, Ibnsouda Koraichi S. 2010. Inventaire et répartition saisonnière des Culicidae dans le centre du Maroc. Entomologie Faunistique, 62(4), 131-138.

58. Elizondo-Quiroga D, Medina-Sanchez A, Sanchez-Gonzalez JM, Eckert KA, Villalobos-Sanchez E, Navarro-Zuniga AR, Sanchez-Tejeda G, Correa-Morales F, Gonzalez-Acosta C, Arias CF, Lopez S, Del Angel RM, Pando-Robles V, Elizondo-Quiroga AE. 2018. Zika Virus in salivary glands of five different species of wild-caught mosquitoes from Mexico. Scientific Reports, 8(1), 809.

59. Ergunay K, Gunay F, Erisoz Kasap O, Oter K, Gargari S, Karaoglu T, Tezcan S, Cabalar M, Yildirim Y, Emekdas G, Alten B, Ozkul A. 2014. Serological, molecular and entomological surveillance demonstrates widespread circulation of West Nile virus in Turkey. PLoS Neglected Tropical Diseases, 8(7), e3028.

60. Ewing DA, Cobbold CA, Purse BV, Nunn MA, White SM. 2016. Modelling the effect of temperature on the seasonal population dynamics of temperate mosquitoes. Journal of Theoretical Biology, 400, 65-79.

61. Failloux AB, Bouattour A, Faraj C, Gunay F, Haddad N, Harrat Z, Jancheska E, Kanani K, Kenawy MA, Kota M, Pajovic I, Paronyan L, Petric D, Sarih M, Sawalha S, Shaibi T, Sherifi K, Sulesco T, Velo E, Gaayeb L, Victoir K, Robert V. 2017. Surveillance of arthropod-borne viruses and their vectors in the Mediterranean and Black Sea regions within the MediLabSecure Network. Current Tropical Medicine Reports, 4(1), 27-39.

62. Fall AG, Diaite A, Etter E, Bouyer J, Ndiaye TD, Konate L. 2012. The mosquito Aedes (Aedimorphus) vexans arabiensis as a probable vector bridging the West Nile virus between birds and horses in Barkedji (Ferlo, Senegal). Medical and Veterinary Entomology, 26(1), 106-111.

63. Faraj C, Adlaoui E, Brengues C, Fontenille D, Lyagoubi M. 2008. Résistance d'Anopheles labranchiae au DDT au Maroc: identification des mécanismes et choix d'un insecticide de remplacement. Eastern Mediterranean Health Journal, 14(4), 776-783.

64. Feng X, Park DS, Liang Y, Pandey R, Papes M. 2019. Collinearity in ecological niche modeling: confusions and challenges. Ecology and Evolution, 9(18), 10365-10376.

65. Ferreira-de-Brito A, Ribeiro IP, Miranda RM, Fernandes RS, Campos SS, Silva KA, Castro MG, Bonaldo MC, Brasil P, 
Lourenco-de-Oliveira R. 2016. First detection of natural infection of Aedes aegypti with Zika virus in Brazil and throughout South America. Memorias do Instituto Oswaldo Cruz, 111(10), 655-658.

66. Gaud J. 1947. Contribution à l'étude des Culicides au Maroc, quatre espèces nouvelles pour la faune locale. Bulletin de la Société des Sciences Naturelles du Maroc, 25-27, 204-206.

67. Gaud J. 1953. Notes biogéographiques sur les Culicidés du Maroc. Archives de l'Institut Pasteur du Maroc, 4, 443-490.

68. GBIF. 2020. GBIF occurrence. Download: https://doi.org/ 10.15468/dl.fygusa.

69. Gendernalik A, Weger-Lucarelli J, Garcia Luna SM, Fauver JR, Ruckert C, Murrieta RA, Bergren N, Samaras D, Nguyen C, Kading RC, Ebel GD. 2017. American Aedes vexans mosquitoes are competent vectors of Zika Virus. American Journal of Tropical Medicine and Hygiene, 96(6), 1338-1340.

70. Germain M, Francy DB, Monath TP, Ferrara L, Bryan J, Salaun JJ, Heme G, Renaudet J, Adam C, Digoutte JP. 1980. Yellow fever in the Gambia, 1978-1979: entomological aspects and epidemiological correlations. American Journal of Tropical Medicine and Hygiene, 29(5), 929-940.

71. Guerbois M, Fernandez-Salas I, Azar SR, Danis-Lozano R, Alpuche-Aranda CM, Leal G, Garcia-Malo IR, Diaz-Gonzalez EE, Casas-Martinez M, Rossi SL, Del Rio-Galvan SL, Sanchez-Casas RM, Roundy CM, Wood TG, Widen SG, Vasilakis N, Weaver SC. 2016. Outbreak of Zika virus infection, Chiapas State, Mexico, 2015, and first confirmed transmission by Aedes aegypti Mosquitoes in the Americas. Journal of Infectious Diseases, 214(9), 1349-1356.

72. Guo C, Zhou Z, Wen Z, Liu Y, Zeng C, Xiao D, Ou M, Han Y, Huang S, Liu D, Ye X, Zou X, Wu J, Wang H, Zeng EY, Jing C, Yang G. 2017. Global epidemiology of dengue outbreaks in 1990-2015: a systematic review and meta-analysis. Frontiers in Cellular and Infection Microbiology, 7, 317.

73. Gutierrez-Lopez R, Bialosuknia SM, Ciota AT, Montalvo T, Martinez-de la Puente J, Gangoso L, Figuerola J, Kramer LD. 2019. Vector competence of Aedes caspius and Ae. albopictus mosquitoes for Zika virus, Spain. Emerging Infectious Diseases, 25(2), 346-348.

74. Guy Y. 1963. Bilan épidémiologique du paludisme au Maroc (données recueillies entre 1960, 1961 et 1962). Annales de Parasitologie Humaine et Comparée, 38(5), 823-857.

75. Guy Y, Holsteun M. 1968. Données récentes sur les Anophèles du Maghreb. Archives de l'Institut Pasteur d'Algérie, 45, 5161.

76. Guy Y, Salieres A, Boesiger E. 1976. Contribution à l'étude du complexe maculipennis (Diptera - Culicidae - Anophelinae). Mise au point en 1975. Annales de Biologie, 15, 5-6.

77. Hammon WM, Reeves WC. 1943. Laboratory transmission of St. Louis Encephalitis Virus by three genera of mosquitoes. Journal of Experimental Medicine, 78(4), 241-253.

78. Handaq N. 1998. Les moustiques du Maroc: écologie et biogéographie des peuplements culicidiens dans les régions montagneuses, semi arides et arides du Maroc occidental : Essai de biotypologie des gîtes larvaires et étude comparative de la dynamique des populations marocaines et tunisiennes. Thèse de Doctorat de 3e cycle, Université Cadi Ayad, Faculté de Sciences Semlalia Marrakech.

79. Handaq N, Blenzar A. 2017. Impact des eaux usées et des aménagements urbains sur la répartition des espèces de Culicidae (Diptera Nematocera) dans la ville de Meknès (Maroc). European Scientific Journal, 13(27), 184-200.

80. Harbach RE. 2012. Culex pipiens: species versus species complex taxonomic history and perspective. Journal of the American Mosquito Control Association, 28(4 Suppl), 10-23.
81. Himmi O. 2007. Les Culicides (Insectes, Diptères) au Maroc: Systématique, écologique et études épidémiologiques pilotes. Rabat, Morocco: Université Mohammed V.

82. Johnson TL, Haque U, Monaghan AJ, Eisen L, Hahn MB, Hayden MH, Savage HM, McAllister J, Mutebi J-P, Eisen RJ. 2017. Modeling the environmental suitability for Aedes (Stegomyia) aegypti and Aedes (Stegomyia) albopictus (Diptera: Culicidae) in the contiguous United States. Journal of Medical Entomology, 54(6), 1605-1614.

83. Boorman JPT. 1958. Transmission of Uganda S virus by Aedes (Stegomyia) aegypti Linn. Transactions of the Royal Society of Tropical Medicine and Hygiene, 52(4), 383-388.

84. Jueterbock A, Smolina I, Coyer JA, Hoarau G. 2016. The fate of the Arctic seaweed Fucus distichus under climate change: an ecological niche modeling approach. Ecology and Evolution, 6(6), 1712-1724.

85. Kamal M, Kenawy MA, Rady MH, Khaled AS, Samy AM. 2018. Mapping the global potential distributions of two arboviral vectors Aedes aegypti and Ae. albopictus under changing climate. PLoS One, 13(12), e0210122.

86. Kantor AM, Lin J, Wang A, Thompson DC, Franz AWE. 2019. Infection pattern of Mayaro Virus in Aedes aegypti (Diptera: Culicidae) and transmission potential of the virus in mixed infections with Chikungunya Virus. Journal of Medical Entomology, 56(3), 832-843.

87. Khormi HM, Kumar L. 2014. Climate change and the potential global distribution of Aedes aegypti: spatial modelling using GIS and CLIMEX. Geospatial Health, 8(2), 405-415.

88. Kraemer MU, Sinka ME, Duda KA, Mylne AQ, Shearer FM, Barker CM, Moore CG, Carvalho RG, Coelho GE, Van Bortel W, Hendrickx G, Schaffner F, Elyazar IR, Teng HJ, Brady OJ, Messina JP, Pigott DM, Scott TW, Smith DL, Wint GR, Golding N, Hay SI. 2015. The global distribution of the arbovirus vectors Aedes aegypti and Ae. albopictus. eLife, 4, e08347.

89. Kraemer MUG, Reiner RC Jr, Brady OJ, Messina JP, Gilbert M, Pigott DM, Yi D, Johnson K, Earl L, Marczak LB, Shirude S, Davis Weaver N, Bisanzio D, Perkins TA, Lai S, Lu X, Jones P, Coelho GE, Carvalho RG, Van Bortel W, Marsboom C, Hendrickx G, Schaffner F, Moore CG, Nax HH, Bengtsson L, Wetter E, Tatem AJ, Brownstein JS, Smith DL, Lambrechts L, Cauchemez S, Linard C, Faria NR, Pybus OG, Scott TW, Liu Q, Yu H, Wint GRW, Hay SI, Golding N. 2019. Past and future spread of the arbovirus vectors Aedes aegypti and Aedes albopictus. Nature Microbiology, 4(5), 854-863.

90. Kraemer MUG, Sinka ME, Duda KA, Mylne A, Shearer FM, Brady OJ, Messina JP, Barker CM, Moore CG, Carvalho RG, Coelho GE, Van Bortel W, Hendrickx G, Schaffner F, Wint GRW, Elyazar IRF, Teng H-J, Hay SI. 2015. The global compendium of Aedes aegypti and Ae. albopictus occurrence. Scientific Data, 2, 150035.

91. Lazear HM, Diamond MS. 2016. Zika virus: new clinical syndromes and its emergence in the Western Hemisphere. Journal of Virology, 90(10), 4864-4875.

92. Li MI, Wong PS, Ng LC, Tan CH. 2012. Oral susceptibility of Singapore Aedes (Stegomyia) aegypti (Linnaeus) to Zika virus. PLoS Neglected Tropical Diseases, 6(8), e1792.

93. Li Y, Li M, Li C, Liu Z. 2020. Optimized Maxent model predictions of climate change impacts on the suitable distribution of Cunninghamia lanceolata in China. Forests, 11(3), 302.

94. Lobo JM, Jiménez-Valverde A, Real R. 2008. AUC: a misleading measure of the performance of predictive distribution models. Global Ecology and Biogeography, 17(2), 145151. 
95. Lourenco-de-Oliveira R, Vazeille M, Bispo de Filippis AM, Failloux AB. 2002. Oral susceptibility to yellow fever virus of Aedes aegypti from Brazil. Memorias do Instituto Oswaldo Cruz, 97(3), 437-439.

96. Lozano-Fuentes S, Kenney JL, Varnado W, Byrd BD, Burkhalter KL, Savage HM. 2019. Susceptibility and vectorial capacity of American Aedes albopictus and Aedes aegypti (Diptera: Culicidae) to American Zika Virus Strains. Journal of Medical Entomology, 56(1), 233-240.

97. Lumley S, Hernández-Triana LM, Horton DL, Fernández de Marco MDM, Medlock JM, Hewson R, Fooks AR, Johnson N. 2018. Competence of mosquitoes native to the United Kingdom to support replication and transmission of Rift Valley fever virus. Parasites \& Vectors, 11(1), 308.

98. Lundstrom JO. 1999. Mosquito-borne viruses in western Europe: a review. Journal of Vector Ecology, 24(1), 1-39.

99. Lwande OW, Naslund J, Lundmark E, Ahlm K, Ahlm C, Bucht G, Evander M. 2019. Experimental infection and transmission competence of Sindbis virus in Culex torrentium and Culex pipiens Mosquitoes from Northern Sweden. VectorBorne and Zoonotic Diseases, 19(2), 128-133.

100. Ma H, Bandos AI, Rockette HE, Gur D. 2013. On use of partial area under the ROC curve for evaluation of diagnostic performance. Statistics in Medicine, 32(20), 3449-3458.

101. Mackenzie-Impoinvil L, Impoinvil DE, Galbraith SE, Dillon RJ, Ranson H, Johnson N, Fooks AR, Solomon T, Baylis M. 2015. Evaluation of a temperate climate mosquito, Ochlerotatus detritus (=Aedes detritus), as a potential vector of Japanese encephalitis virus. Medical and Veterinary Entomology, 29(1), 1-9.

102. Magalhaes T, Robison A, Young MC, Black WCt, Foy BD, Ebel GD, Ruckert C. 2018. Sequential infection of Aedes aegypti mosquitoes with Chikungunya Virus and Zika Virus enhances early Zika Virus transmission. Insects, 9(4), 177.

103. Main BJ, Nicholson J, Winokur OC, Steiner C, Riemersma KK, Stuart J, Takeshita R, Krasnec M, Barker CM, Coffey LL. 2018. Vector competence of Aedes aegypti, Culex tarsalis, and Culex quinquefasciatus from California for Zika virus. PLOS Neglected Tropical Diseases, 12(6), e0006524.

104. Mancini G, Montarsi F, Calzolari M, Capelli G, Dottori M, Ravagnan S, Lelli D, Chiari M, Santilli A, Quaglia M, Quaglia M, Federici V, Monaco F, Goffredo M, Savini G. 2017. Mosquito species involved in the circulation of West Nile and Usutu viruses in Italy. Veterinaria Italiana, 53(2), 97-110.

105. Mavale MS, Ilkal MA, Dhanda V. 1992. Experimental studies on the susceptibility of Aedes vittatus to dengue viruses. Acta Virologica, 36(4), 412-416.

106. Mavridis K, Fotakis EA, Kioulos I, Mpellou S, Konstantas S, Varela E, Gewehr S, Diamantopoulos V, Vontas J. 2018. Detection of West Nile Virus - Lineage 2 in Culex pipiens mosquitoes, associated with disease outbreak in Greece, 2017. Acta Tropica, 182, 64-68.

107. Medlock JM, Cull B, Vaux AGC, Irwin AG. 2017. The mosquito Aedes vexans in England. Veterinary Record, 181(9), 243.

108. Medlock JM, Hansford KM, Versteirt V, Cull B, Kampen H, Fontenille D, Hendrickx G, Zeller H, Van Bortel W, Schaffner F. 2015. An entomological review of invasive mosquitoes in Europe. Bulletin of Entomological Research, 105(6), 637-663.

109. Metge G. 1986. Étude des écosystèmes hydromorphes (Daya et Merja) de la Meseta occidentale marocaine. Typologie et synthèse cartographique à objectif sanitaire, appliquée aux populations d'Anopheles labranchiae (Falleroni, 1926) (Diptera, Culicidae, Anophelinae). Marseille, France: Université Aix-Marseille.
110. Metge G. 1991. Contribution à l'étude écologique d'Anopheles labranchae au Maroc: activité des imagos et dynamique des stades pré-imaginaux de la région Sidi Bettache. Bulletin d'Écologie, 22(3-4), 419-426.

111. Metge G, Hassaïne K. 1998. Study of the environmental factors associated with oviposition by Aedes caspius and Aedes detritus along a transect in Algeria. Journal of the American Mosquito Control Association, 14(3), 283-288.

112. Miller BR, Godsey MS, Crabtree MB, Savage HM, Al-Mazrao Y, Al-Jeffri MH, Abdoon AM, Al-Seghayer SM, Al-Shahrani AM, Ksiazek TG. 2002. Isolation and genetic characterization of Rift valley fever virus from Aedes vexans arabiensis, Kingdom of Saudi Arabia. Emerging Infectious Diseases, 8 (12), 1492-1494.

113. Mint Lekweiry K, Ould Ahmedou Salem MS, Ould Brahim K, Ould Lemrabott MA, Brengues C, Faye O, Simard F, Ould Mohamed Salem Boukhary A. 2015. Aedes aegypti (Diptera: Culicidae) in Mauritania: first report on the presence of the Arbovirus mosquito vector in Nouakchott. Journal of Medical Entomology, 52(4), 730-733.

114. Morales NS, Fernández IC, Baca-González V. 2017. MaxEnt's parameter configuration and small samples: are we paying attention to recommendations? A systematic review. PeerJ, 5, e3093.

115. O'Donnell KL, Bixby MA, Morin KJ, Bradley DS, Vaughan JA. 2017. Potential of a Northern population of Aedes vexans (Diptera: Culicidae) to transmit Zika Virus. Journal of Medical Entomology, 54(5), 1354-1359.

116. Orshan L, Bin H, Schnur H, Kaufman A, Valinsky A, Shulman L, Weiss L, Mendelson E, Pener H. 2008. Mosquito vectors of West Nile fever in Israel. Journal of Medical Entomology, 45 (5), 939-947.

117. Osorio-Olvera L, Lira-Noriega A, Soberón J, Peterson AT, Falconi M, Contreras-Díaz RG, Martínez-Meyer E, Barve V, Barve N. 2020. ntbox: an R package with graphical user interface for modelling and evaluating multidimensional ecological niches. Methods in Ecology and Evolution, 11, 1199-1206.

118. Osorio-Olvera L, Vijay B, Narayani B, Jorge S, Manuel F. 2018. ntbox: from getting biodiversity data to evaluating species distribution models in a friendly GUI environment. $\mathrm{R}$ package version 0.2.5.4. [cited 2019 10/10]. Available from: https://github.com/luismurao/ntbox.

119. Pearson RG, Raxworthy CJ, Nakamura M, Townsend PA. 2007. Original Article: predicting species distributions from small numbers of occurrence records: a test case using cryptic geckos in Madagascar. Journal of Biogeography, 34(1), 102117.

120. Peterson AT, Papeş M, Soberón J. 2008. Rethinking receiver operating characteristic analysis applications in ecological niche modeling. Ecological Modelling, 213(1), 63-72.

121. Phillips SJ, Anderson RP, Schapire RE. 2006. Maximum entropy modeling of species geographic distributions. Ecological Modelling, 190(3-4), 231-259.

122. Pilaski J, Mackenstein H. 1985. Isolation of Tahyna virus from mosquitoes in 2 different European natural foci. Zentralblatt fur Bakteriologie, Mikrobiologie und Hygiene. 1. Abt. Originale B Hygiene, 180(4), 394-420.

123. Powers AM. 2016. Epidemiological History of Chikungunya Virus, in Chikungunya Virus: Advances in Biology, Pathogenesis, and Treatment, Okeoma CM, Editor. Springer International Publishing: Cham. p. 33-44.

124. Puggioli A, Bonilauri P, Calzolari M, Lelli D, Carrieri M, Urbanelli S, Pudar D, Bellini R. 2017. Does Aedes albopictus (Diptera: Culicidae) play any role in Usutu virus transmission 
in Northern Italy? Experimental oral infection and field evidences. Acta Tropica, 172, 192-196.

125. Qiao H, Peterson AT, Campbell LP, Soberón J, Ji L, Escobar LE. 2016. NicheA: creating virtual species and ecological niches in multivariate environmental scenarios. Ecography, 39 (8), 805-813.

126. Radosavljevic A, Anderson RP. 2014. Making better Maxent models of species distribu-tions: complexity, overfitting and evaluation. Journal of Biogeography, 41(4), 629-643.

127. Ravanini P, Huhtamo E, Ilaria V, Crobu MG, Nicosia AM, Servino L, Rivasi F, Allegrini S, Miglio U, Magri A, Minisini R, Vapalahti O, Boldorini R. 2012. Japanese encephalitis virus RNA detected in Culex pipiens mosquitoes in Italy. Eurosurveillance, 17(28), 20221.

128. Reynolds ES, Hart CE, Hermance ME, Brining DL, Thangamani S. 2017. An overview of animal models for arthropodborne viruses. Comparative Medicine, 67(3), 232-241.

129. Richard V, Paoaafaite T, Cao-Lormeau VM. 2016. Vector competence of French Polynesian Aedes aegypti and Aedes polynesiensis for Zika Virus. PLoS Neglected Tropical Diseases, 10(9), e0005024.

130. Robert V, Gunay F, Le Goff G, Philippe B, Şuleşco T, Khalin A, Medlock J, Kampen H, Petrić D, Schaffner F. 2019. Distribution chart for Euro-Mediterranean mosquitoes (western Palaearctic region). Journal of the European Mosquito Control Association, 37, 1-28.

131. Roehrig JT. 2013. West Nile virus in the United States - a historical perspective. Viruses, 5(12), 3088-3108.

132. Roiz D, Ruiz S, Soriguer R, Figuerola J. 2014. Climatic effects on mosquito abundance in Mediterranean wetlands. Parasites \& Vectors, 7, 333.

133. Ruiz-Arrondo I, McMahon BJ, Hernández-Triana LM, Santibañez P, Portillo A, Oteo JA. 2019. Surveillance of Mosquitoes (Diptera, Culicidae) in a Northern Central Region of Spain: implications for the medical community. Frontiers in Veterinary Science, 6, 86 .

134. Severini F, Boccolini D, Fortuna C, Di Luca M, Toma L, Amendola A, Benedetti E, Minelli G, Romi R, Venturi G, Rezza G, Remoli ME. 2018. Vector competence of Italian Aedes albopictus populations for the Chikungunya Virus (E1226V). PLoS Neglected Tropical Diseases, 12(4), e0006435.

135. Shcheglovitova M, Anderson RP. 2013. Estimating optimal complexity for ecological niche models: a jackknife approach for species with small sample sizes. Ecological Modelling, 269, 9-17.

136. Simões MVP, Peterson AT, Hassall C. 2018. Utility and limitations of climate-matching approaches in detecting different types of spatial errors in biodiversity data. Insect Conservation and Diversity, 11(5), 407-414.

137. Smartt CT, Stenn TMS, Chen TY, Teixeira MG, Queiroz EP, Souza Dos Santos L, Queiroz GAN, Ribeiro Souza K, Kalabric Silva L, Shin D, Tabachnick WJ. 2017. Evidence of Zika Virus RNA fragments in Aedes albopictus (Diptera: Culicidae) fieldcollected eggs from Camacari, Bahia, Brazil. Journal of Medical Entomology, 54(4), 1085-1087.

138. Sudeep AB, Shil P. 2017. Aedes vittatus (Bigot) mosquito: an emerging threat to public health. Journal of Vector Borne Diseases, 54(4), 295-300.

139. Tantely LM, Boyer S, Fontenille D. 2015. A review of mosquitoes associated with Rift valley fever virus in Mada- gascar. American Journal of Tropical Medicine and Hygiene, 92(4), 722-729.

140. Trari B. 2017. Les moustiques (Insectes, Diptères) du Maroc: atlas de répartition et études épidémiologiques. Thèse de doctorat d'état. Rabat, Morocco: Université Mohammed V Faculté des sciences de Rabat.

141. Trari B, Dakki M, Harbach RE. 2017. An updated checklist of the Culicidae (Diptera) of Morocco, with notes on species of historical and current medical importance. Journal of Vector Ecology, 42(1), 94-104.

142. Trari B, Dakki M, Himmi O, el Agbani MA. 2003. Les moustiques (Diptera Culicidae) du Maroc. Revue bibliographique (1916-2001) et inventaire des espèces. Bulletin de la Société de Pathologie Exotique, 96(4), 329-334.

143. Tsuda Y, Suwonkerd W, Chawprom S, Prajakwong S, Takagi M. 2006. Different spatial distribution of Aedes aegypti and Aedes albopictus along an urban-rural gradient and the relating environmental factors examined in three villages in northern Thailand. Journal of the American Mosquito Control Association, 22(2), 222-228.

144. Tsuda Y, Takagi M. 2001. Survival and development of Aedes aegypti and Aedes albopictus (Diptera: Culicidae) larvae under a seasonally changing environment in Nagasaki, Japan. Environmental Entomology, 30, 855-860.

145. Turell MJ, Presley SM, Gad AM, Cope SE, Dohm DJ, Morrill JC, Arthur RR. 1996. Vector competence of Egyptian mosquitoes for Rift Valley fever virus. American Journal of Tropical Medicine and Hygiene, 54(2), 136-139.

146. Vazeille M, Jeannin C, Martin E, Schaffner F, Failloux AB. 2008. Chikungunya: a risk for Mediterranean countries? Acta Tropica, 105(2), 200-202.

147. Veronesi R, Gentile G, Carrieri M, Maccagnani B, Stermieri L, Bellini R. 2012. Seasonal pattern of daily activity of Aedes caspius, Aedes detritus, Culex modestus, and Culex pipiens in the Po Delta of northern Italy and significance for vector-borne disease risk assessment. Journal of Vector Ecology, 37(1), 4961.

148. Versteirt V, Ducheyne E, Schaffner F, Hendrickx G. 2013. Systematic literature review on the geographic distribution of rift valley fever vectors in Europe and the neighbouring countries of the Mediterranean Basin. Supporting Publications 2013: EN-412. p. 59.

149. Vialatte C. 1923. Contribution à la recherche de l'aire de dispersion de Stegomyia fasciata. Son existence à Marrakech. Archives de l'Institut Pasteur d'Algérie, 1, 688-690.

150. Viamonte JMR, Ramirez A. 1946. Culicinos de la zona española de Marruecos. Revista de Sanidad e Higiene Pública, 20, 449-455.

151. Warren D, Matzke N, Cardillo M, Baumgartner J, Beaumont L, Huron N, Simões M, Dinnage R. 2019. ENMTools (software package). [cited 2020 01-05]. Available from: https://github.com/danlwarren/ENMTools.

152. Warren DL, Glor RE, Turelli M. 2010. ENMTools: a toolbox for comparative studies of environmental niche models. Ecography, 33(3), 607-611.

153. WHO. 2016. WHO statement on the first meeting of the International Health Regulations 2005 (IHR 2005) Emergency Committee on Zika Virus and observed increase in neurological disorders and neonatal malformations. [cited 2020 10/09]. Available from: http://www.who.int/mediacentre/news/ statements/2016/1st-emergency-committee-zika/en/. 
An international open-access, peer-reviewed, online journal publishing high quality papers on all aspects of human and animal parasitology

Reviews, articles and short notes may be submitted. Fields include, but are not limited to: general, medical and veterinary parasitology; morphology, including ultrastructure; parasite systematics, including entomology, acarology, helminthology and protistology, and molecular analyses; molecular biology and biochemistry; immunology of parasitic diseases; host-parasite relationships; ecology and life history of parasites; epidemiology; therapeutics; new diagnostic tools.

All papers in Parasite are published in English. Manuscripts should have a broad interest and must not have been published or submitted elsewhere. No limit is imposed on the length of manuscripts.

Parasite (open-access) continues Parasite (print and online editions, 1994-2012) and Annales de Parasitologie Humaine et Comparée (1923-1993) and is the official journal of the Société Française de Parasitologie. 